\title{
Differential Responses of Resistant Soybean Entries to Isolates of Phakopsora pachyrhizi
}

T. A. Pham, Department of Crop Sciences, National Soybean Research Center (NSRC), University of Illinois, Urbana; M. R. Miles, United States Department of Agriculture-Agricultural Research Service (USDA-ARS), NSRC, Urbana, IL 61801; R. D. Frederick, USDA-ARS, Foreign Disease-Weed Science Research Unit, Ft. Detrick, MD 21702; C. B. Hill, Department of Crop Sciences, NSRC, University of Illinois; and G. L. Hartman, USDA-ARS and Department of Crop Sciences, NSRC, University of Illinois, Urbana

\begin{abstract}
Pham, T. A., Miles, M. R., Frederick, R. D., Hill, C. B., and Hartman, G. L. 2009. Differential responses of resistant soybean entries to isolates of Phakopsora pachyrhizi. Plant Dis. 93:224228.

Soybean rust, caused by the fungus Phakopsora pachyrhizi, was detected in the continental United States in 2004. Several new sources of resistance to $P$. pachyrhizi have been identified in soybean (Glycine max); however, there is limited information about their resistance when challenged with additional U.S. and international isolates. Resistance of 20 soybean (G. max) entries was compared after inoculation with $10 P$. pachyrhizi isolates, representing different geographic and temporal origins. Soybean entries included 2 universal susceptible cultivars, 4 sources of soybean rust resistance genes $\left(R p p_{1-4}\right)$, and 4 and 10 resistant entries selected from field trials in Paraguay and Vietnam, respectively. Of the known $R p p_{I-4}$ sources of resistance, plant introduction (PI) 459025B $\left(R p p_{4}\right)$ produced reddish-brown (RB) lesions in response to all of the $P$. pachyrhizi isolates, while PI $230970\left(R p p_{2}\right)$ produced RB lesions to all isolates except one from Taiwan, in response to which it produced a susceptible tan (TAN) lesion. PI $200492\left(R p p_{1}\right)$ and PI $462312\left(R_{p p}\right)$ produced TAN lesions in response to most $P$. pachyrhizi isolates. The resistant entries selected from Paraguay and Vietnam varied considerably in their responses to the $10 P$. pachyrhizi isolates, with M 103 the most susceptible and GC 84058-18-4 the most resistant. The reaction patterns on these resistant entries to the P. pachyrhizi isolates were different compared with the four soybean accessions with the Rpp genes, indicating that they contain novel sources of rust resistance. Among the P. pachyrhizi isolates, TW 72-1 from Taiwan and IN 73-1 from India produced the most susceptible and resistant reactions, respectively, on the soybean entries.
\end{abstract}

Phakopsora pachyrhizi Syd. \& P. Syd., the cause of soybean rust, is an economically important pathogen of soybean. Since $P$. pachyrhizi was first reported in Japan in 1902 (11), it has been reported in many other countries in the Eastern Hemisphere throughout the last 100 years (4). More recently, soybean rust was found in the United States; it was first reported in Hawaii in 1994 (12) and subsequently in the continental United States in Louisiana in 2004 (23). P. pachyrhizi can cause significant yield losses under favorable environmental conditions $(10,19,28)$.

Corresponding author: G. L. Hartman

E-mail: ghartman@uiuc.edu

Trade and manufacturers' names are necessary to report factually on available data; however, the USDA neither guarantees nor warrants the standard of the product, and the use of the name by USDA implies no approval of the product to the exclusion of others that may also be suitable.

Accepted for publication 11 August 2008.

doi:10.1094/PDIS-93-3-0224

This article is in the public domain and not copyrightable. It may be freely reprinted with customary crediting of the source. The American Phytopathological Society, 2009.
Three different reaction types occur on soybean in response to $P$. pachyrhizi infection: (i) an immune (IM) reaction without visible lesions, (ii) a resistant reaction with reddish-brown (RB) lesions, and (iii) a susceptible reaction with $\tan$ (TAN) lesions (4). Field collections of $P$. pachyrhizi differing in virulence have been reported based on the development of TAN lesions produced on a set of differential hosts $(2,6,14)$.

A geographically diverse collection of $P$. pachyrhizi isolates from different countries has been maintained and stored at the United States Department of AgricultureAgricultural Research Service (USDAARS) Foreign Disease-Weed Science Research Unit (FDWSRU) Biosafety Level 3 (BSL-3) plant pathogen containment facility at Ft. Detrick, MD since 1972 $(3,17)$. This collection has been used to study diversity in virulence and aggressiveness $(2,5,16)$. Whereas isolates from Taiwan and Indonesia produced significantly more urediniospores per lesion per day than other isolates, an isolate from India penetrated soybean leaf tissue faster and produced more lesions per unit leaf area (16). In another study at the FDWSRU, an isolate from Taiwan consistently produced more uredinia per lesion at a given time on a susceptible soybean plant than did an isolate from India-73-1 (5). Recently, $12 P$. pachyrhizi isolates in the FDWSRU collection were inoculated onto soybean accessions with known rust resistance and many were found to produce TAN lesions (2).

In addition to the soybean rust research at FDWSRU, work elsewhere has examined specific interactions between soybean entries and $P$. pachyrhizi isolates. In 1966, researchers in Taiwan observed different reaction types on five legume species in response to nine $P$. pachyrhizi isolates, although all of the soybean entries tested had susceptible tan lesions (14). In a subsequent experiment conducted in Taiwan in 1983, 50 single-urediniospore isolates of $P$. pachyrhizi inoculated onto the five soybean entries-plant introduction (PI) 462312 (Ankur), TK\#5, TN 4, PI 200492 (Komata), and PI 230971-were differentiated into three physiological races based upon specific reaction patterns of $\mathrm{RB}$ and TAN lesions (27).

Physiological races of $P$. pachyrhizi also have been reported in Australia, China, and Japan. In Australia, one race was virulent on soybean cv. Williams and avirulent on PI 200492, while another race was virulent on both soybean entries (15). In another study, six races of $P$. pachyrhizi were identified using 257 entries from six Glycine spp. (6). In China, seven $P$. pachyrhizi isolates were differentiated into four races using a set of eight soybean entries (24). In Japan, $18 P$. pachyrhizi races were differentiated using 11 soybean entries based upon reaction type and the number of uredinia produced per lesion (26).

Potential new sources of rust resistance were found in the USDA-ARS soybean germplasm collection (18) and from recent field evaluations in Paraguay and Vietnam $(20,25)$. Both locations identified plant introductions from field assessments that had been short-listed as possible resistant sources based on greenhouse evaluations (18), and some of the resistant sources were used in our study. Host-parasite interaction between $P$. pachyrhizi and soybean in North America has not been extensively studied. The objective of this study was to evaluate $10 \mathrm{P}$. pachyrhizi isolates that represent different geographic and temporal origins with 20 soybean entries 
that included newly identified sources of resistance $(18,20,25)$.

\section{MATERIALS AND METHODS}

Pathogen isolates. The $P$. pachyrhizi isolates used in this study are described in Table 1. Three isolates, two from Alabama and one from Louisiana, were collected from the 2004 outbreak in the United States and increased through four successive rounds of single pustule purification on soybean cv. Williams. Seven other isolates, collected as far back as 1972 from Asia, Africa, and South America and used in several previous studies $(2,5,16)$, also were included. Urediniospores of each of the 10 isolates of $P$. pachyrhizi were increased separately on Williams soybean. Newly formed urediniospores were harvested with a cyclone collector (7), beginning approximately 10 to14 days after inoculation and continuing at weekly intervals. Urediniospores were stored under liquid nitrogen $\left(-196^{\circ} \mathrm{C}\right)$ at the USDAARS, FDWSRU, BSL-3 Containment Facility.

Plant materials. The 20 soybean entries used in this study are shown in Table 2. These entries were chosen to represent the four known sources of single resistant genes $\left(R p p_{1-4}\right)$, a selection of resistant entries from field trials in Paraguay and Vietnam, and two susceptible cultivars that consistently produced TAN lesions $(9,20,25)$.

Experimental procedure. The first trial was conducted in August 2006 and was repeated in April 2007. Experimental design for each trial was a split plot arranged in two randomized complete blocks. The $10 \mathrm{P}$. pachyrhizi isolates were the main plots and 20 soybean entries were the subplots. Five seeds of each entry were planted in 9-by-9-cm pots filled with Sunshine LC1 Mix (Sun Grow Horticulture Products, Belleview, VA) and thinned to three plants after germination. The experimental units were the pots of three plants of each soybean entry. Each main plot, consisting of one experimental unit of each of the 20 soybean entries in randomized order, was contained inside a single 38-by-47-cm flat (Hummert International, Earth City, MO). Seedlings at the second and third fully expanded trifoliolate leaf stage in each flat were inoculated with a single P. pachyrhizi isolate. Pots were fertilized with 14-14-14 Osmocote (ScottsSierra Horticultural Products Co., Marysville, $\mathrm{OH})$ at planting and were maintained in a walk-in growth chamber (Environmental Growth Chambers, Chagrin Falls, $\mathrm{OH})$ at $25^{\circ} \mathrm{C}, 60 \%$ relative humidity, under a 16-h photoperiod provided by a mixture of high-pressure sodium vapor and highintensity discharge (metal halide) lamps giving approximately $250 \mu$ moles $\mathrm{s}^{-1} \mathrm{~m}^{-2}$ PAR.

Inoculation procedure. Prior to inoculation, stored urediniospores were removed from liquid nitrogen and heat shocked at $40^{\circ} \mathrm{C}$ for $5 \mathrm{~min}(2)$. Urediniospores were hydrated overnight by floating them in a small plastic weigh boat on sterile distilled water in a petri dish. Inoculum of each isolate was prepared by suspending urediniospores in $0.1 \%$ Tween 20 (sodium monolaurate) in sterile distilled water, mixing vigorously, and filtering through a $53-\mu \mathrm{m}$ pore size screen. Urediniospore concentration was adjusted by means of a hemacytometer to $5 \times 10^{4}$ urediniospores/ml for inoculation.

Inoculum $(100 \mathrm{ml})$ was applied to each flat of plants at the second to third fully expanded trifoliolate leaf stage by means of an atomizer at $1.4 \times 10^{5} \mathrm{~Pa}$. The plants were incubated inside dew chambers at $20^{\circ} \mathrm{C}$ for $24 \mathrm{~h}$. The two replications were inoculated 2 days apart. Urediniospore viability was determined by spraying inoculum of each isolate onto the surface of sterile water agar in petri dishes and determining the percent germination after 24 $\mathrm{h}$ of incubation at $20^{\circ} \mathrm{C}$.

Plants were removed from the dew chambers and placed in the greenhouse at $25^{\circ} \mathrm{C}$. Supplemental illumination was provided by $1,000-\mathrm{W}$ metalarc lights (Sylvania, Danvers, MA) spaced $0.6 \mathrm{~m}$ apart above the bench. Pots were placed in metal trays and watered from the bottom.

Disease ratings. Reaction type and relative sporulation levels were evaluated 14 days after inoculation. Reaction types were recorded as IM, RB, or TAN. Relative sporulation levels in RB lesions was rated using a 1-to-5 scale, relative to the sporula-

Table 1. Phakopsora pachyrhizi isolates used to evaluate the response of 20 soybean entries inoculated under controlled conditions in the greenhouse

\begin{tabular}{lllcl}
\hline Isolate & \multicolumn{1}{c}{ Country } & \multicolumn{1}{c}{ Location } & Year collected & \multicolumn{1}{c}{ Source } \\
\hline AL04-1 & United States & Mobile County, Alabama & 2004 & R. Frederick $^{\mathrm{a}}$ \\
AL04-3 & United States & Baldwin County, Alabama & 2004 & R. Frederick $^{\mathrm{a}}$ \\
BZ01-1 & Brazil & Parana & 2001 & J. T. Yoriniori $^{\text {b }}$ \\
IN 73-1 & India & Pantnagar & 1973 & D. N. Thapliyal \\
LA04-1 & United States & Ben Hur, Louisiana & 2004 & R. Schneider $^{\mathrm{d}}$ \\
PG01-2 & Paraguay & Capitán Miranda & 2001 & W. Morel $^{\mathrm{e}}$ \\
TH01-1 & Thailand & Chaingmai & 2001 & S. Poonpolgul $^{\mathrm{f}}$ \\
TW 72-1 & Taiwan & Taipei & 1972 & L. C. Wu $^{\mathrm{g}}$ \\
TW 80-2 & Taiwan & Taipei & 1980 & AVRDC $^{\mathrm{g}}$ \\
ZM 01-1 & Zimbabwe & Harare & 2001 & C. Levy $^{\mathrm{h}}$ \\
\hline
\end{tabular}

a Collections made with the assistance of T. Johnson, R. Wingard, and W. Harrison, Alabama Department of Agriculture and Industries, Montgomery; and E. Sikora, Alabama Cooperative Extension System, Auburn University, Auburn, AL.

b Embrapa soja, Londrina, Brazil.

c Govind Ballabh Pant University of Agriculture and Technology, Pantnagar, India.

d Department of Plant Pathology and Crop Physiology, Louisiana State University, Baton Rouge.

e Centro Regional de Investigación Agrícola, Capitán Miranda, Itapúa, Paraguay.

f Thailand Department of Agriculture, Bangkok, Thailand.

g Asian Vegetable Research and Development Center, Taipei, Taiwan.

${ }^{\mathrm{h}}$ Commercial Farmers Union of Zimbabwe, Harare, Zimbabwe.

Table 2. Name, origin, and source of seed of soybean entries inoculated with Phakopsora pachyrhizi under controlled greenhouse conditions

\begin{tabular}{llll}
\hline Entry & \multicolumn{1}{c}{ Reason selected $^{\mathbf{a}}$} & \multicolumn{1}{c}{ Origin $^{\mathbf{b}}$} & Source $^{\mathbf{c}}$ \\
\hline PI 200492 $\left(R_{p p}\right)$ & Resistance gene & Japan & USDA-ARS \\
PI 230970 $\left(R_{p}\right)$ & Resistance gene & Japan & USDA-ARS \\
PI 462312 $\left(R p p_{3}\right)$ & Resistance gene & India & USDA-ARS \\
PI 459025B $\left(R p p_{4}\right)$ & Resistance gene & Fujian, China & USDA-ARS \\
PI 587886 & Paraguay field trial & Zhejiang, China & USDA-ARS \\
PI 587905 & Paraguay field trial & Zhejiang, China & USDA-ARS \\
PI 605833 & Paraguay field trial & HaGiang, Vietnam & USDA-ARS \\
PI 594754 & Paraguay field trial & Guangxi, China & USDA-ARS \\
PI 437323 & Vietnam field trial & Primorye, Russian Federation & USDA-ARS \\
PI 423972 & Vietnam field trial & Kumamoto, Japan & USDA-ARS \\
DT 12 & Susceptible check & Hanoi, Vietnam & PPRI \\
DT 2000 & Vietnam field trial & AVRDC, Taiwan & PPRI \\
DT 95 & Vietnam field trial & Hanoi, Vietnam & PPRI \\
DT 96 & Vietnam field trial & Hanoi, Vietnam & PPRI \\
GC 84058-18-4 & Vietnam field trial & AVRDC, Taiwan & PPRI \\
M 103 & Vietnam field trial & Hanoi, Vietnam & PPRI \\
Nhat Tien Huu Lung Lang Son & Vietnam field trial & Lang Son, Vietnam & PPRI \\
VX 93 & Vietnam field trial & Hanoi, Vietnam & PPRI \\
Cao Bang U8352 & Vietnam field trial & Cao Bang, Vietnam & PPRI \\
Williams 82 & Susceptible check & Illinois, USA & USDA-ARS \\
\hline
\end{tabular}

\footnotetext{
a Resistance genes (9), Paraguay field trial (20), and Vietnam field trial (26).

${ }^{b}$ AVRDC $=$ the Asian Vegetable Research Development Center.

${ }^{c}$ USDA-ARS = United States Department of Agriculture-Agricultural Research Service, Urbana, IL and PPRI = the Plant Protection Research Institute, Hanoi, Vietnam. 
tion in the susceptible Williams 82, where $1=$ no sporulation, 2 = sporulation less than $25 \%$ of the fully sporulating lesions on Williams $82,3=$ sporulation equal to 26 to $50 \%$ of the fully sporulating lesions on Williams $82,4=$ sporulation equal to 51 to $75 \%$ of the fully sporulating lesions on Williams 82 , and $5=$ sporulation similar to a fully sporulating TAN lesion on Williams 82.

Leaf preparation for uredinial counts. Leaflets were evaluated on the 20 soybean entries inoculated with isolates AL 04-1, LA 04-1, TH 01-1, and TW 72-1 from trial 2. Three leaf pieces from leaflets of each soybean entry- $P$. pachyrhizi isolate combination from each of the two replications were excised and placed in Farmer's solution (ethanol:acetic acid [3:1, vol/vol]) for $16 \mathrm{~h}$, then submerged in lactophenol for 24 $\mathrm{h}$ to remove leaf pigments (2). A $1-\mathrm{cm}^{2}$ leaf piece which visually represented the lesion density of the selected leaflet was cut out of each leaflet and stained overnight in lactophenol containing $0.1 \%$ cotton blue (2). Excess stain was removed from the surface of the leaf pieces by briefly rinsing in lactophenol. The leaf pieces were mounted by placing them in a pool of lactophenol in an inverted petri dish lid, placing additional drops of lactophenol on the surface of the leaflets by means of a Pasteur pipette, and then placing a petri dish bottom into the lid to sandwich the sample, surrounded by lactophenol, between two pieces of plastic. The stained leaf pieces were examined microscopically at $\times 100$ and $\times 400$. The average number of uredinia per lesion was determined from 10 lesions on each leaf piece.

Data analyses. Urediniospore germination, sporulation ratings, and lesion counts were analyzed using the restricted maximum likelihood (REML) procedure in JMP 5 (SAS Institute, Cary, NC). For each isolate, the percentage that caused TAN lesions across the entries was calculated as (the number of entries with TAN lesions/total number of entries) $\times 100$. For each entry, the percentage of RB or IM response across isolates was calculated as (the number of RB/IM responses/total number of isolates) $\times 100$. Ordinal data from the rating scales for relative sporulation levels were ranked, using the Rank procedure of SAS (SAS Institute Inc.), for each accession inoculated with each isolate within each replication and inoculation date. The ranks were analyzed by analysis of variance using the Mixed procedure with the anovaf option and REML estimation. Differences in least squares means within each entry-isolate combination and the susceptible cv. Williams 82 were generated with lsmeans statements and difference options within the Mixed procedure of SAS. For uredinia counts, lsmeans for accessions and isolates were generated and compared by Student's least significant difference. Single-degree contrasts were made for the test of lesion and uredinia counts using JMP 5.

\section{RESULTS}

Urediniospore germination. There was a difference in germination rate between the two trials but not among $P$. pachyrhizi isolates within a trial. The germination rates of $P$. pachyrhizi isolates in the second trial were significantly higher than in the first trial. Overall mean germination rates of the 10 isolates in the first and second trial were 28 and $67 \%$, respectively.

Reaction type. The qualitative data on lesion types were combined from the two trials (Table 3). All 10 P. pachyrhizi isolates produced TAN lesions on the susceptible entries, Williams 82 and DT 12, as well as on M103.

Of the 40 interactions of the $10 \mathrm{P}$. pachyrhizi isolates on the known sources of $R p p_{1-4}$ resistance, one was IM, 22 were $\mathrm{RB}$, and 16 were TAN. PI $200492\left(R p p_{1}\right)$ produced an IM reaction with the $P$. pachyrhizi isolate IN 73-1, RB lesions with the isolate LA 04-1, and TAN lesions with eight isolates. PI $230970\left(R p p_{2}\right)$ produced RB lesions with all of the $P$. pachyrhizi isolates, except for TW 80-2, where TAN lesions were observed. PI $462313\left(R_{p p} p_{3}\right)$ produced RB lesions with isolates BZ 011, IN 73-1, and LA 04-1 and TAN lesions with seven isolates. PI 459025B $\left(R_{p p}\right)$ produced RB lesions with all of the isolates.

Table 3. Reaction types and relative sporulation levels of soybean entry by isolate combinations that produced a reddish-brown (RB)-colored lesion or an immune reaction (IR) based on 20 soybean entries 14 days after inoculation with 10 Phakopsora pachyrhizi isolates under controlled greenhouse conditions

\begin{tabular}{|c|c|c|c|c|c|c|c|c|c|c|c|}
\hline \multirow[b]{2}{*}{ Entry } & \multicolumn{10}{|c|}{ Isolates $^{a}$} & \multirow[b]{2}{*}{$\mathbf{R B} / \operatorname{IM}(\%)^{\mathbf{b}}$} \\
\hline & IN 73-1 & AL 04-1 & TH 01-1 & ZM 01-1 & TW 80-2 & PG 01-2 & LA 04-1 & BZ 01-1 & AL 04-3 & TW 72-1 & \\
\hline PI 459025B $\left(R p p_{4}\right)$ & $\mathrm{RB} / 2.8$ & $\mathrm{RB} / 2.4$ & $\mathrm{RB} / 2.7$ & $\mathrm{RB} / 2.5$ & $\mathrm{RB} / 2.5$ & $\mathrm{RB} / 2.5$ & $\mathrm{RB} / 3.1$ & $\mathrm{RB} / 2.3$ & $\mathrm{RB} / 2.0$ & $\mathrm{RB} / 2.8$ & 100 \\
\hline GC 84058-18-4 & $\mathrm{RB} / 1.8$ & $\mathrm{RB} / 2.3$ & $\mathrm{RB} / 2.5$ & $\mathrm{RB} / 2.9$ & $\mathrm{RB} / 2.2$ & $\mathrm{RB} / 2.2$ & $\mathrm{RB} / 2.8$ & $\mathrm{RB} / 2.8$ & $\mathrm{RB} / 2.6$ & ND & 100 \\
\hline PI $230970\left(R p p_{2}\right)$ & $\mathrm{RB} / 1.7$ & $\mathrm{RB} / 3.0$ & $\mathrm{RB} / 2.5$ & $\mathrm{RB} / 2.1$ & $\mathrm{~T}$ & $\mathrm{RB} / 2.2$ & $\mathrm{RB} / 2.0$ & $\mathrm{RB} / 2.3$ & $\mathrm{RB} / 1.2$ & $\mathrm{RB} / 1.7$ & 90 \\
\hline PI 587886 & $\mathrm{RB} / 1.0$ & $\mathrm{RB} / 1.2$ & $\mathrm{RB} / 2.0$ & $\mathrm{RB} / 1.7$ & $\mathrm{RB} / 2.2$ & $\mathrm{RB} / 2.3$ & $\mathrm{~T}$ & $\mathrm{RB} / 1.8$ & $\mathrm{RB} / 1.2$ & $\mathrm{RB} / 3.0$ & 90 \\
\hline DT 95 & $\mathrm{RB} / 1.2$ & $\mathrm{RB} / 2.6$ & $\mathrm{RB} / 2.6$ & $\mathrm{RB} / 2.5$ & $\mathrm{RB} / 2.9$ & $\mathrm{RB} / 2.3$ & $\mathrm{RB} / 1.6$ & $\mathrm{RB} / 2.8$ & $\mathrm{~T}$ & $\mathrm{~T}$ & 80 \\
\hline PI 594754 & $\mathrm{IM} / 1.0$ & $\mathrm{RB} / 1.3$ & $\mathrm{RB} / 2.0$ & $\mathrm{RB} / 1.4$ & $\mathrm{RB} / 1.0$ & $\mathrm{RB} / 1.0$ & $\mathrm{~T}$ & $\mathrm{~T}$ & $\mathrm{RB} / 1.0$ & ND & 78 \\
\hline PI 587905 & $\mathrm{RB} / 1.2$ & $\mathrm{RB} / 1.5$ & $\mathrm{RB} / 2.2$ & $\mathrm{RB} / 1.9$ & $\mathrm{RB} / 1.9$ & $\mathrm{RB} / 2.2$ & $\mathrm{~T}$ & $\mathrm{~T}$ & $\mathrm{RB} / 2.0$ & ND & 78 \\
\hline Cao Bang U8352 & $\mathrm{RB} / 1.5$ & $\mathrm{RB} / 2.1$ & $\mathrm{RB} / 3.0$ & $\mathrm{RB} / 2.3$ & $\mathrm{RB} / 2.3^{\mathrm{c}}$ & $\mathrm{RB} / 2.3$ & $\mathrm{~T}$ & $\mathrm{RB} / 2.5$ & $\mathrm{~T}^{\mathrm{c}}$ & $\mathrm{T}$ & 70 \\
\hline PI 605833 & $\mathrm{RB} / 1.0$ & $\mathrm{RB} / 2.3$ & $\mathrm{RB} / 2.2$ & $\mathrm{RB} / 2.5$ & $\mathrm{RB} / 2.6$ & $\mathrm{RB} / 2.3$ & $\mathrm{~T}$ & $\mathrm{~T}$ & $\mathrm{RB} / 2.8$ & $\mathrm{~T}$ & 70 \\
\hline DT 2000 & $\mathrm{RB} / 1.6$ & $\mathrm{RB} / 2.1$ & $\mathrm{RB} / 3.1$ & $\mathrm{RB} / 2.6$ & $\mathrm{RB} / 3.6$ & ND & $\mathrm{RB} / 1.5$ & $\mathrm{~T}$ & $\mathrm{~T}$ & $\mathrm{~T}$ & 67 \\
\hline PI 423972 & $\mathrm{~T}$ & $\mathrm{RB} / 2.8$ & $\mathrm{RB} / 3.3$ & $\mathrm{RB} / 3.2$ & $\mathrm{RB} / 2.7^{\mathrm{c}}$ & ND & $\mathrm{RB} / 2.7$ & $\mathrm{~T}^{\mathrm{c}}$ & $\mathrm{T}$ & $\mathrm{T}$ & 56 \\
\hline NTHLLS $^{d}$ & $\mathrm{~T}$ & $\mathrm{RB} / 2.8$ & $\mathrm{RB} / 2.8$ & $\mathrm{RB} / 2.5$ & $\mathrm{RB} / 2.7$ & ND & $\mathrm{T}$ & $\mathrm{RB} / 3.1$ & $\mathrm{~T}$ & $\mathrm{~T}$ & 56 \\
\hline PI $462312\left(R p p_{3}\right)$ & $\mathrm{RB} / 2.9$ & $\mathrm{~T}$ & $\mathrm{~T}$ & $\mathrm{~T}$ & $\mathrm{~T}$ & $\mathrm{~T}$ & $\mathrm{RB} / 2.0$ & $\mathrm{RB} / 2.0^{\mathrm{c}}$ & $\mathrm{T}$ & $\mathrm{T}$ & 30 \\
\hline PI 437323 & $\mathrm{~T}$ & $\mathrm{~T}$ & $\mathrm{~T}^{\mathrm{c}}$ & $\mathrm{T}$ & $\mathrm{T}^{\mathrm{c}}$ & $\mathrm{RB} / 3.9$ & $\mathrm{RB} / 3.8$ & $\mathrm{~T}$ & $\mathrm{~T}$ & $\mathrm{~T}$ & 20 \\
\hline DT 96 & $\mathrm{RB} / 1.0$ & $\mathrm{~T}$ & $\mathrm{~T}$ & $\mathrm{~T}$ & $\mathrm{~T}$ & $\mathrm{~T}$ & $\mathrm{RB} / 1.5^{\mathrm{c}}$ & $\mathrm{T}$ & $\mathrm{T}^{\mathrm{c}}$ & $\mathrm{T}^{\mathrm{c}}$ & 20 \\
\hline PI $200492\left(R p p_{l}\right)$ & IM/1.0 & $\mathrm{T}$ & $\mathrm{T}$ & $\mathrm{T}$ & $\mathrm{T}$ & $\mathrm{T}$ & $\mathrm{RB} / 1.6$ & $\mathrm{~T}$ & $\mathrm{~T}$ & $\mathrm{~T}$ & 10 \\
\hline VX 93 & $\mathrm{~T}$ & $\mathrm{~T}$ & $\mathrm{~T}$ & $\mathrm{~T}$ & $\mathrm{~T}$ & $\mathrm{~T}$ & $\mathrm{RB} / 2.4$ & $\mathrm{~T}$ & $\mathrm{~T}$ & $\mathrm{~T}$ & 10 \\
\hline M 103 & $\mathrm{~T}$ & $\mathrm{~T}$ & $\mathrm{~T}$ & $\mathrm{~T}$ & $\mathrm{~T}$ & $\mathrm{~T}$ & $\mathrm{~T}$ & $\mathrm{~T}$ & $\mathrm{~T}$ & $\mathrm{~T}$ & 0 \\
\hline DT 12 & $\mathrm{~T}$ & $\mathrm{~T}$ & $\mathrm{~T}$ & $\mathrm{~T}$ & $\mathrm{~T}$ & $\mathrm{~T}$ & $\mathrm{~T}$ & $\mathrm{~T}$ & $\mathrm{~T}$ & $\mathrm{~T}$ & 0 \\
\hline Williams 82 & $\mathrm{~T}$ & $\mathrm{~T}$ & $\mathrm{~T}$ & $\mathrm{~T}$ & $\mathrm{~T}$ & $\mathrm{~T}$ & $\mathrm{~T}$ & $\mathrm{~T}$ & $\mathrm{~T}$ & $\mathrm{~T}$ & 0 \\
\hline TAN (\%) & 35 & 40 & 40 & 40 & 45 & 41 & 45 & 60 & 65 & 82 & $\ldots$ \\
\hline
\end{tabular}

a Designated based on country and year of origin. IN 73-1: India 1973, ZM 01-1: Zimbabwe 2001, AL 04-1: Alabama 2004, BZ 01-1: Brazil 2001, PG 01-2: Paraguay 2001, TH 01-1: Thailand 2001, TW 80-2: Taiwan 1980, LA 04-1: Louisiana 2004, AL 04-3: Alabama 2004, and TW 72-1: Taiwan 1972. Relative sporulation level within RB lesions was rated using a 1-to-5 scale, where $1=$ no sporulation, $2=$ sporulation less than $25 \%$ of the fully sporulating lesions on susceptible check cv. Williams $82,3=$ sporulation equals to 26 to $50 \%$ of the fully sporulating lesions on Williams $82,4=$ sporulation equals to 51 to $75 \%$ of the fully sporulating lesions on Williams 82 , and $5=$ sporulation similar to a fully sporulating TAN lesion of Williams 82 . ND $=$ not determined because the plants had primarily mixed reactions with no predominant lesion type. $\mathrm{T}=\mathrm{TAN}$ lesions, where sporulation levels were not evaluated on entryisolate combinations that produced TAN lesions.

b Percent of entries that produced either RB lesions, an IM with no visible symptoms, or both.

c Data not based on the entire set of three plants per each of two replications per trial.

${ }^{\mathrm{d}}$ Nhat Tien Huu Lung Lang Son. 
Of the 40 interactions of the 10 isolates on the four resistant entries from Paraguay, 1 was IM, 39 were RB, 8 were TAN, and 2 were not determined (Table 3). PI 587866 produced RB lesions with nine isolates and TAN lesions with isolate LA04-1. PI594754 produced an IM response with isolate IN 73-1, RB lesions with six isolates, and TAN lesions with three isolates. PI 587905 and PI 605833 each produced RB lesions with seven of the same $P$. pachyrhizi isolates.

The 10 accessions selected for resistance in Vietnam also differed in their reaction to the 10 isolates used in the study and tended to have fewer $\mathrm{RB}$ reactions (Table 3). GC 84058-18-4 produced RB lesions with nine of the $P$. pachyrhizi isolates. DT 95 and Cao Bang U8352 produced RB lesions with eight and seven isolates, respectively, and were similar in reaction pattern. DT 2000 produced RB lesions with six isolates while Nhat Tien Huu Lung Lang Sun and PI 423972 each produced RB lesions with five isolates, PI 437323 and DT 96 each produced RB lesions with two isolates, VX93 produced an RB reaction to one isolate, and M 103 produced TAN lesions to all isolates.

When comparisons were made across the isolates used in the study, $P$. pachyrhizi isolate TW 72-1 produced the most TAN reactions among the soybean entries (82\%), whereas isolate IN 73-1 produced the fewest $(35 \%)$. Three soybean entries (PI459025B, GC84058-18-4, and PI 230970) produced $\mathrm{RB}$ reactions with all three U.S. isolates.
Relative sporulation of uredinia in the RB reactions. There was a difference in relative sporulation levels between the two trials, but the trial-isolate-entry interaction was not significant; therefore, data from the two trials were combined. There was an isolate-entry interaction, indicating that there was a differential response of entries to isolates for relative sporulation levels among entries with RB lesions. The relative $\mathrm{RB}$ sporulation ratings ranged from 1.0 to 3.9 , and were all lower than Williams 82 (Table 3).

Uredinial counts. There was a significant isolate-entry interaction for number of uredinia per lesion (Table 4). Overall, there were more uredinia in TAN lesions (average of 3.5 uredinia/lesion) than in RB lesions (average of 2.1 uredinia/lesion). Single degree of freedom comparison contrasts showed differences within some of the RB reaction types. For example, GC 84058-18-4 and PI 459025B inoculated with isolate TH 01-1 produced fewer uredinia per lesion compared with numbers from the other isolates. In contrast, PI $230970\left(R p p_{2}\right)$ did not differ in the number of uredinia per lesion among the four isolates. Similar comparisons could be made within the TAN reaction types as well. For example, there were fewer uredinia per lesion on entry DT 12 when inoculated with isolate TW 72-1 compared with the three other isolates.

\section{DISCUSSION}

Host specialization of rust fungi is well documented and examples include wheat stem rust (Puccinia graminis f. sp. tritici), wheat leaf rust ( $P$. triticina), and barley rust $(P$. hordei) $(13,21,22)$. A gene-for-gene interaction regulates the interaction between the host and pathogen (8). Resistance or incompatibility occurs when a resistance gene in the host corresponds with an avirulence gene in the fungus, whereas compatibility results from an avirulent isolate on a host genotype lacking the corresponding resistance gene or when a specific resistance allele is matched by a corresponding virulence allele (8). In our study, soybean entries differed in their response to Phakopsora pachyrhizi isolates, which demonstrates physiologic specialization of this fungus on soybean. There were 14 unique reaction type profiles (soybean entry-P. pachyrhizi isolate combinations). Five soybean entries did not produce a differential response. These included PI 459025B (source of $R_{p p}$ ) and GC84058-18-4, both of which had only RB reactions, and M103 and the two susceptible checks DT12 and Williams 82 , which had only TAN reactions to all the isolates.

A standard set of soybean differentials has yet to be established, but our research and earlier research done at the FDWSRU (1) may provide the basis for establishing an effective differential set of soybean genotypes to distinguish soybean rust pathotypes based on virulence patterns. Not only will an effective set of soybean differentials provide information on virulence diversity, it also will be useful to determine whether resistance is due to a previously characterized resistance gene or to a new gene or genes. For example, many

Table 4. Number of uredinia per lesion (U/L) on 20 soybean accessions inoculated with four Phakopsora pachyrhizi isolates under controlled greenhouse conditions

\begin{tabular}{|c|c|c|c|c|c|c|c|c|c|c|c|c|c|}
\hline \multirow[b]{3}{*}{ Entry } & \multicolumn{12}{|c|}{ Isolate $^{\mathrm{a}}$} & \multirow[b]{3}{*}{ Mean } \\
\hline & \multicolumn{3}{|c|}{ AL 04-1 } & \multicolumn{3}{|c|}{ LA 04-1 } & \multicolumn{3}{|c|}{ TH 01-1 } & \multicolumn{3}{|c|}{ TW 72-1 } & \\
\hline & $\mathbf{U} / \mathbf{L}$ & Rank & Type & $\mathbf{U} / \mathbf{L}$ & Rank & Type & $\mathbf{U} / \mathbf{L}$ & Rank & Type & $\mathbf{U} / \mathbf{L}$ & Rank & Type & \\
\hline DT 95 & 0.0 & 1 & $\mathrm{RB}$ & 0.0 & 1 & $\mathrm{RB}$ & 1.7 & 7 & $\mathrm{RB}$ & 3.6 & 7 & $\mathrm{~T}$ & 1.3 \\
\hline DT 2000 & 0.0 & 1 & $\mathrm{RB}$ & 0.0 & 1 & $\mathrm{RB}$ & 2.8 & 15 & $\mathrm{RB}$ & 5.0 & 14 & $\mathrm{~T}$ & 2.0 \\
\hline PI $200492\left(R p p_{l}\right)$ & 1.3 & 3 & $\mathrm{~T}$ & 1.3 & 3 & $\mathrm{RB}$ & 2.1 & 10 & $\mathrm{~T}$ & 2.9 & 2 & $\mathrm{~T}$ & 1.9 \\
\hline PI $462312\left(R p p_{3}\right)$ & 1.7 & 4 & $\mathrm{~T}$ & 1.7 & 4 & $\mathrm{RB}$ & 2.1 & 10 & $\mathrm{~T}$ & 4.4 & 11 & $\mathrm{~T}$ & 2.5 \\
\hline DT 96 & 1.7 & 4 & $\mathrm{~T}$ & - & - & $\mathrm{RB}$ & 2.3 & 13 & $\mathrm{~T}$ & 3.4 & 6 & $\mathrm{~T}$ & 2.3 \\
\hline PI 587886 & 1.8 & 6 & $\mathrm{RB}$ & 1.8 & 6 & $\mathrm{~T}$ & 1.6 & 6 & $\mathrm{RB}$ & 1.5 & 1 & $\mathrm{RB}$ & 1.7 \\
\hline PI 423972 & 2.1 & 7 & $\mathrm{RB}$ & 2.1 & 7 & $\mathrm{RB}$ & 1.0 & 3 & $\mathrm{RB}$ & 2.9 & 2 & $\mathrm{~T}$ & 2.0 \\
\hline Nhat Tien HLLS & 2.2 & 8 & RB & 2.2 & 8 & $\mathrm{~T}$ & 0.9 & 2 & $\mathrm{RB}$ & 4.3 & 10 & $\mathrm{~T}$ & 2.4 \\
\hline CaoBang U8352 & 2.3 & 9 & $\mathrm{RB}$ & 2.3 & 9 & $\mathrm{~T}$ & 2.2 & 12 & $\mathrm{RB}$ & 3.6 & 7 & $\mathrm{~T}$ & 2.6 \\
\hline PI 437323 & 2.4 & 10 & $\mathrm{~T}$ & 2.4 & 10 & $\mathrm{RB}$ & 1.4 & 5 & $\mathrm{~T}$ & 3.3 & 5 & $\mathrm{~T}$ & 2.4 \\
\hline PI 605833 & 2.6 & 11 & $\mathrm{RB}$ & 2.6 & 11 & $\mathrm{~T}$ & 1.9 & 8 & $\mathrm{RB}$ & 3.7 & 8 & $\mathrm{~T}$ & 2.7 \\
\hline GC 84058-18-4 & 2.7 & 12 & $\mathrm{RB}$ & 2.7 & 12 & $\mathrm{RB}$ & 2.0 & 9 & $\mathrm{RB}$ & - & - & ND & 2.6 \\
\hline VX 93 & 2.8 & 13 & $\mathrm{~T}$ & 2.8 & 13 & $\mathrm{RB}$ & 3.8 & 16 & $\mathrm{~T}$ & 3.7 & 8 & $\mathrm{~T}$ & 3.3 \\
\hline PI 587905 & 3.1 & 14 & $\mathrm{RB}$ & 3.1 & 14 & $\mathrm{~T}$ & 1.0 & 3 & $\mathrm{RB}$ & - & - & ND & 2.3 \\
\hline PI 459025B $\left(R p p_{4}\right)$ & 3.2 & 15 & $\mathrm{RB}$ & 3.2 & 15 & $\mathrm{RB}$ & 2.3 & 13 & $\mathrm{RB}$ & 3.1 & 4 & $\mathrm{RB}$ & 3.0 \\
\hline M103 & 3.3 & 16 & $\mathrm{~T}$ & 3.3 & 16 & $\mathrm{~T}$ & 4.3 & 17 & $\mathrm{~T}$ & 4.5 & 12 & $\mathrm{~T}$ & 3.9 \\
\hline PI 594754 & 4.3 & 17 & RB & 4.3 & 17 & $\mathrm{~T}$ & 0.0 & 1 & $\mathrm{RB}$ & - & - & ND & 2.5 \\
\hline Williams 82 & 4.3 & 17 & $\mathrm{~T}$ & 4.3 & 17 & $\mathrm{~T}$ & 5.4 & 19 & $\mathrm{~T}$ & 4.8 & 13 & $\mathrm{~T}$ & 4.7 \\
\hline PI $230970\left(R p p_{2}\right)$ & 4.5 & 19 & $\mathrm{RB}$ & 4.5 & 19 & $\mathrm{RB}$ & 4.3 & 17 & $\mathrm{RB}$ & 5.0 & 14 & RB & 4.6 \\
\hline DT 12 & 7.0 & 20 & $\mathrm{~T}$ & 7.0 & 20 & $\mathrm{~T}$ & 7.9 & 20 & $\mathrm{~T}$ & 5.3 & 16 & $\mathrm{~T}$ & 6.8 \\
\hline Mean & 2.7 & $\ldots$ & $\ldots$ & 2.7 & $\ldots$ & $\ldots$ & 2.6 & $\ldots$ & $\ldots$ & 3.5 & $\ldots$ & $\ldots$ & $\ldots$ \\
\hline $\operatorname{LSD}_{0.05}{ }^{\mathrm{b}}$ & 1.0 & $\ldots$ & $\ldots$ & $\ldots$ & $\ldots$ & $\ldots$ & $\ldots$ & $\ldots$ & $\ldots$ & $\ldots$ & $\ldots$ & $\ldots$ & $\ldots$ \\
\hline
\end{tabular}

${ }^{a}$ Designated based on country and year of origin: Alabama (AL) 04-1, Louisiana (LA) 04-1, Thailand (TH) 01-1, and Taiwan (TW) 72-1. RB = reddish-

brown lesions and $\mathrm{T}=$ tan-colored lesions; $-=$ no data recorded due to missing plants and $\mathrm{ND}=$ not determined due to a mixed results.

${ }^{\mathrm{b}}$ LSD $=$ least significant difference; means were compared by using Student's $t$ test with $P=0.05$ and $t=1.97$. 
recently identified sources of resistance used in this study had reaction patterns different from the genotypes possessing the resistance genes $R p p_{1-4}$, suggesting that additional resistance genes are present in these genotypes. Although this is not definitive, this information provides the basis to pursue genetic allelism tests and, subsequently, map any new, unique resistance genes found.

Most $P$. pachyrhizi isolates used in this study produced a unique reaction type profile on the 20 soybean entries. A few isolates had the same profile and some were similar, with just a single response difference among the soybean entries. The geographic origin of isolate was not associated with the reaction profiles. The three U.S. isolates AL 04-1, AL 04-3, and LA 04-1 produced $\mathrm{RB}$ reactions on the sources of $R p p_{2}$ and $R p p_{4}$, while only LA 04-1 produced an RB reaction on the source of $R p p_{1}$. However, the three isolates differed in reaction pattern on a number of entries, including PI $462312\left(R_{p p}\right)$. These three isolates were all collected in the United States in 2004 after the first report of soybean rust in the continental United States (24). Two of the isolates, AL 04-1 and LA 04-1, were collected from soybean and the other (AL 04-3) from kudzu. Preliminary screening of these isolates with a simple sequence marker demonstrated genetic diversity (1). Further work is needed to compare the evolution of lineages of these isolates with other isolates both inside and outside the United States.

The number of soybean differentials needed may depend on the inherent variability of $P$. pachyrhizi and its potential to develop biotypes that overcome more resistance genes. Our study and others (2) have shown that most isolates overcome at least one of the known resistance genes. Currently, no known single genes for resistance to soybean rust have been deployed in the United States. Our results show that the known genes for resistance to soybean rust may be vulnerable. Breeding soybean for resistance to soybean rust may be complicated by lack of knowledge of the hostparasite interaction; therefore, non-hostspecific resistance needs to be pursued in conjunction with the more traditional approach of single-gene resistance. For example, partial resistance (expressed as reduced pustule number), increased length of latent period, and other parameters such as reduced sporulation and yield stability (which compares yield performance of cultivars often in side-by-side fungicide and nonfungicide plots) need further consideration because these schemes may alleviate the selection of $P$. pachyrhizi isolates that overcome single-gene resistance (9).

\section{ACKNOWLEDGMENTS}

We thank B. Nguyen (the Plant Protection Research Institute, Hanoi, Vietnam) and R. Nelson and his staff (USDA Soybean Germplasm Collection Center Urbana, IL) for providing soybean seed used in this study, and J. Bowers (USDA-ARS FDWSRU, Ft. Detrick, MD) for technical help. This research was supported in part by the Foreign Agricultural Service, Illinois Soybean Association, North Central Soybean Research Program, and the United Soybean Board.

\section{LITERATURE CITED}

1. Anderson, S. J., Stone, C. L., Posada-Buitrago, M. L., Boore, J. L., Neelam, B. A., Stephens, R. M., Luster, D. G., Frederick, R. D., and Pedley, K. F. 2008. Development of simple sequence repeat markers for the soybean rust fungus, Phakopsora pachyrhizi. Mol. Econ. Res. doi:10.1111/j.1755-0998.2008.02272.x.

2. Bonde, M. R., Nester, S. E., Austin, C. N., Stone, C. L., Frederick, R. D., Hartman, G. L., and Miles, M. R. 2006. Evaluation of virulence of Phakopsora pachyrhizi and P. meibomiae isolates. Plant Dis. 90:708-716.

3. Bonde, M. R., and Peterson, G. L. 1995. Research at the USDA, ARS Containment Facility on soybean rust and its causal agent. Pages 12-18 in: Proc. Soybean Rust Workshop. J. B. Sinclair and G. L. Hartman, eds. College of Agricultural, Consumer, and Environmental Sciences, National Soybean Research Laboratory, Urbana, IL.

4. Bromfield, K. R. 1984. Soybean Rust. Monograph No. 11. American Phytopathological Society, St. Paul, MN.

5. Bromfield, K. R., Melching, J. S., and Kingsolver, C. H. 1980. Virulence and aggressiveness of Phakopsora pachyrhizi isolates causing soybean rust. Phytopathology 70:17-21.

6. Burdon, J. J., and Speer, S. S. 1984. A set of differential Glycine hosts for the identification of races of Phakopsora pachyrhizi Syd. Euphytica 33:891-896.

7. Cherry, E., and Peet, C. 1966. An efficient device for the rapid collection of fungal spores from infected plants. Phytopathology 56:11021103.

8. Deverall, B. J. 1989. Mechanisms of resistance and pathogenic specialization in rust-wheat interactions. New Phytol. 113:233-244.

9. Hartman, G. L., Miles, M. R., and Frederick, R. D. 2005. Breeding for resistance to soybean rust. Plant Dis. 89:664-666.

10. Hartman, G. L., Wang, T. C., and Tschanz, A. T. 1991. Soybean rust development and the quantitative relationship between rust severity and soybean yield. Plant Dis. 75:596-600.

11. Hennings, P. 1903. Some new Japanese Uredinales. Hedwigia (Suppl.) IV:107-108.

12. Killgore, E., and Heu, R. 1994. First report of soybean rust in Hawaii. Plant Dis. 78:1216.

13. Kolmer, J. A., Jin, Y., and Long, D. L. 2007. Leaf and stem rust of wheat in the United States. J. Aust. Agric. Res. 58:631-638.

14. Lin, S. Y. 1966. Studies on the physiologic races of soybean rust fungus, Phakopsora pachyrhizi Syd. J. Taiwan Agric. Res. 15:2428.

15. McLean, R. J., and Byth, D. E. 1977. Resistance of soybean to rust in Australia. Pages 5861 in: Rust of Soybean-the Problem and Research Needs. INTSOY Ser. No. 12. R. E. Ford and J. B. Sinclair, eds. University of Illinois, Urbana.

16. Melching, J. S., Bromfield, K. R., and Kingsolver, C. H. 1979. Infection, colonization, and uredospore production on Wayne soybean by four cultures of Phakopsora pachyrhizi, the cause of soybean rust. Phytopathology 69:1262-1265.

17. Melching, J. S., Bromfield, K. R., and Kingsolver, C. H. 1983. The plant pathogen containment facility at Frederick, Maryland. Plant Dis. 67:717-722.

18. Miles, M. R., Frederick, R. D., and Hartman, G. L. 2006. Evaluation of soybean germplasm for resistance to Phakopsora pachyrhizi. Plant Health Progress doi 10.1094/PHP-2006-010401-RS.

19. Miles, M. R., Levy, C., Morel, W., Mueller, T., Steinlage, T., van Rij, N., Frederick, R. D., and Hartman, G. L. 2007. International fungicide efficacy trials for the management of soybean rust. Plant Dis. 91:1450-1458.

20. Miles, M. R., Morel, W., Ray, J. D., Smith, J. R., Frederick, R. D., and Hartman, G. L. 2008. Adult plant evaluation of soybean accessions for resistance to Phakopsora pachyrhizi in the field and greenhouse in Paraguay. Plant Dis. 92:96-105.

21. Park, R. F., and Felsenstein, F. G. 1998. Physiological specialization and pathotype distribution of Puccinia recondita in western Europe. Plant Pathol. 47:157-164.

22. Sawhney, R. N., and Goel, L. B. 1981. Racespecific interactions between wheat genotypes and Indian cultures of stem rust. Theor. Appl. Genet. 60:161-166.

23. Schneider, R. W., Hollier, C. A., Whitman, H. K., Palm, M. E., McKemy, J. M., Hernández, J. R., Levy, L., and DeVries-Paterson, R. 2005. First report of soybean rust caused by Phakopsora pachyrhizi in the continental United States. Plant Dis. 89:774.

24. Tan, Y. J., and Sun, Y. L. 1989. Preliminary studies on physiological races of soybean rust. Soybean Sci. (China) 8:71-74.

25. Vuong, T. D., Pham, A. T., Nguyen, B. T., Tram, L. D., Nguyen, H., Van Toai, T., Miles, M. R., and Hartman, G. L. 2005. Evaluation of soybean germplasm for soybean rust (Phakopsora pachyrhizi) resistance in Ha Noi, Vietnam. Poster presented at the National Soybean Rust Symposium, Nashville, TN.

26. Yamaoka, Y., Fujiwara, Y., Kakishima, M., Katsuya, K., Yamada, K., and Hagiwara, H. 2002. Pathogenic races of Phakopsora pachyrhizi on soybean and wild host plants collected in Japan. J. Gen. Plant Pathol. 68:52-56.

27. Yeh, C. C. 1983. Physiological races of Phakopsora pachyrhizi in Taiwan. J. Agric. Res. China 32:69-74

28. Yorinori, J. T., Paiva, W. M., Frederick, R. D., Costamilan, L. M., Bertagnoli, P. F., Hartman, G. E., Godoy, C. V., and Nunes, J., Jr. 2005. Epidemics of soybean rust (Phakopsora pachyrhizi) in Brazil and Paraguay from 2001 to 2003. Plant Dis. 89:675-677.

\section{ERRATUM}

This article was changed on 23 February 2009 in two places. On page 226, in RESULTS, in the third paragraph, isolate LA 04-2 was changed to LA 04-1 in two places. On page 228, in DISCUSSION, in the first full paragraph, the fourth sentence was changed. 